\title{
School Principal Competence in Developing School Culture to Complete Facilities and Infrastructure Supporting Curriculum Implementation in Primary School
}

\author{
Nina Lamatenggo ${ }^{a}$, Nurlina Panigoro ${ }^{a}$ \\ a Universitas Negeri Gorontalo
}

\begin{abstract}
The object of this study was to obtain description about management competence of school principal in managing school facilities and infrastructures which supporting curriculum implementation. Particularly, objective of this study was to find out the image of primary school facilities and infrastructures in Gorontalo province, which is about: (1) The situation of a) work force (teachers), (b) buildings, (c) media, (d) output, (e) financial, and (f) prosperity of primary school teachers in Gorontalo Province, (2) Specific condition of primary school facilities and infrastructures in Gorontalo Province, (3) Major supporting factor which determined the quality of primary school facilities and infrastructures in Gorontalo Province, (4) steps and programs to increase support strength of school facilities and infrastructures in primary school study performance in Gorontalo Province, (5) Parameters of primary school facilities and infrastructures in Gorontalo Province. This study involved college students majoring in MP which were preparing their thesis and currently composing their research proposal. The research of lecture academic showed that (a) Facilities and infrastructures, procurement of classrooms and teachers, which qualified and complied the competencies, were not meeting the minimum service standard in Gorontalo Regency; furthermore, it was observed that study-supporting facilities in the form of laboratorium, which equipped with IPA, IPS, and ICT tools, was not owned yet by all schools, only about $58 \%$ good facilities were found in SD, MI,SMP, STs which located in Gorontalo Regency. College student findings about school culture was that developing ESQ-based school culture via intracuriculer actions in SMP Negeri I Gorontalo, which in this case was study process inside the classrooms where teachers applied the culture of greetings, help student get used to pray before study so that the study process can be done well, implanted the need to care for each other by giving positive motivations. From college student findings about K-13 practice evaluation it was observed that overall, the curriculum of 2013 is not ready to be implemented.
\end{abstract}

Keywords: school principal competence, school culture, primary school curriculum, school facilities and infrastructures

\section{INTRODUCTION}

School principal competence in managing primary school institution is very important, especially in developing school culture that conducive including managing school facilities an infrastructures which could help implementation of school curriculum. Competence of school principal was intentionally built through various training in hope that the school he/she leads can develop, in context of quantity and quality. This school development is associated with how school principal can develop conducive school culture in order achieve good education management.

Education regulation, particularly about education quality, become the responsibility of regional government. Central government, in certain respects, is always controlling educational programs, specifically programs about quality standard, but greater authority was given to the regional government. This situation was a consequence of regional autonomy that was given to regions to develop its potentials (natural resources and human resources) according to the necessities.

Each year, through national or regional programs, various facilities and infrastructures developments were done, but we could always find school in poor state, for example a tilted school building with cracked walls, without tiles, hollow roofs, and broken seats that could harm students, no instructional media, etc. Furthermore, there is a lack of harmony between 
school committee support and principal and the teachers.

Conditions that mentioned above become big obstacles to improve education quality. To resolve these obstacles, two things were needed, i.e. (1) what is the condition of the infrastructure, and (2) which factor is the major support that determine the quality of school infrastructures, (3) what steps were done to improve the ability of school infrastructures to support education, (4) what programs were done to develop school facilities and infrastructures, in order to support education process in school, and (5) what programs were done in steps to improve the ability of school infrastructures to support the quality of education.

\section{THEORETICAL REVIEW}

\subsection{School Facilities and Infrastructures Theories}

To organize education, we required (1) clear purpose, (2) planning and estimating the quality of outcomes, (3) educational process, (4) input (5) resources, and (6) facilities and infrastructures. Quality Assurance (QA) of facilities and infrastructures in educational process, also inspiring for research and community service, that were parts of Tridharma Perguruan Tinggi. Facilities and infrastructures are a part of input, whilst input is one of the subsystems from system that determines organization of education.

Facilities and infrastructures are important parts which were needed to prepare very carefully and continuous, that we can ensure there is always a continuous improvement. Facilities and infrastructures that important are highly dependent on the needs of related institution. Therefore researches about facilities and infrastructures give inspirations to education providers that policy about facilities and infrastructures is an open ended solution. Which means, very important facilities and infrastructures are very dependent on certain situation and condition, but education providers are required to do their best within existing limitations. With all these existing limitations it was necessary to determine the best current actions and future development plan.

To determined best facilities and infrastructures, it should be discussed with related parties, by providing an existing framework, thereby produced optimization of the use of current facilities and infrastructures, and the probability to add new facilities and infrastructures. Generally, infrastructures owned by providers of primary education in Indonesia always contain a gap between idealism and reality. There is nothing to worry about. The solution for this matter is continuous optimization technique (continuous improvement), determine standard parameters as minimum reference for education providers.

Standard parameters of facilities and infrastructures contain totality of the education providers that require the infrastructures, specifically (1) building standards and environmental health, (2) PS standards of educational facilities, (3) PS standards of learning resources, (4) preparation, operation, maintenance and restoration standards of equipment's, (5) general infrastructure standards in the form of water, electricity, and telephone, etc..

Facilities and infrastructures are one of eight education standards that always standardized in educational operations at every level of education. Nevertheless, facilities and infrastructures are closely related to various factors in education and for that reason the discussion about school facilities and infrastructures should be combined with other factors that need to be taken into account for determining existence of school facilities and infrastructures, viz. (a) human resources (teacher), (b) buildings, (c) media for learning, (d) outputs, (e) financial, and (f) prosperity of teachers.

Generally in every school, most dominant facilities and infrastructures are; (1) study desks and chairs for students, (2) whiteboard or blackboard, (3) package of learning textbooks, (4) library, (5) laboratory, etc. Most important facilities and infrastructures like (1) water source, (2) toilet, (3) school cafeteria, and (4) musholla, are almost forgotten.

\subsection{School Culture Theories}

Culture is a knowledge, belief, values that were adopted by a community of people. People inherited these customs from older generations and maintained as their current cultures.

School cultures are: (1) the determinants of how school energy and structures transform into useful things; (2) the system of school values which will affect the way work is done and the behaviour of school community; (3) built from firmly held beliefs about how schools should be organized or operated; (4) a system where there is a shared purpose in school community that distinguish one school from others; and (5) a system where there is shared feeling, which is a set of important characteristics in the form of the values of the school itself (Masaong and Tilome, 2011:179). 
School excellence is not only specified by visible or tangible factors like splendid building, complete facilities, or education level of human resources; but it is also specified by other invisible or intangible factors, viz. school culture ( masaong and tilome, 2011-185). (2011:29). A system of basic assumptions, values, beliefs, and customs that shared by whole school community, which are trusted and proved could be used to confront any problems in adapting to new environment and performing internal integration, that this system of assumptions and values could be taught to other member and new generation so they have the correct ideas of how they should understand, think, feel, and act in front of any existing situations and environments.

According to Masaong and Tilome (2011:194), school culture affected by various factors, i.e.: a) teaching enthusiasm of teachers, b) mastery of teaching materials, c) school discipline, d) learning process, e) right schedule, f) attitudes teachers to students, and g) leadership of school principal.

School culture is the meaning that adopted by the school, and the school culture also differentiates the school from others. School culture has assumptions, values and customs, held by school community. School culture is also inseparable from various factors that influence it, and school culture also has its own values that develop in the schools to produce better schools and not only have excellent performance but also good moral and behaviour from the school community.

Basicly, school culture concept can be used to see where positive and negative changes could happen in micro context (school) also become a model for continuous evaluation to enhance the quality. School also has freedom to make work programs from government through Standar Kompetensi Lulusan (SKL) which is one of eight national education standards as mention in Peraturan Menteri Pendidikan Nasional (Permen) No. 23, year 2006. Favourite schools should have integrated school culture development system and be implemented in the learning process.

\subsection{Evaluation of Curriculum Implementation Theories}

Evaluation is an action to gather information about how things work, then these information are used to determine the right alternatives to take a decision. Evaluation of a program aims to see if the program was planned, held, and beneficial for related parties. In the execution, program evaluation was done to find information as many as we could to obtain an illustration of design and execution of the program. Result of the evaluation then used for related parties to take important decisions.

\subsubsection{Evaluation Execution Procedure}

Evaluation of education consists primarily of three factors, namely input, process and output. If the procedure is run without oriented to those three factors then it is concerned that the final illustration from the evaluation result will not describe correctly the real pictures that happened in the learning process. Generally, the steps to execute the education evaluation are: (Node, 2008:20-21):

1. Planning (why evaluation was needed, which things need evaluation, evaluation goal, evaluation techniques, who would be evaluated, when, where, instruments construction, indicators, and what kind of data we need to find.

2. Data accumulation (test, observation, questionnaire, etc., appropriate to the objectives).

3. Data verification (instrument test, validation test, reliability test).

4. Data processing (Translation of collected, qualitative or quantitative data, whether the data needs to be processed with statistics or nonstatistics, whether it is to be processed by parametric or non-parametric, manual or using software; for example: SAS, SPSS).

5. Data interpreting (interpreted through various testing techniques, finalized by hypothesis test, rejected or approved).

\subsubsection{Evaluation Goals}

Every activity undertaken must have an objective, as well as on evaluation. According to Arikunto (2002:13), there are two objectives of evaluation, namely general objectives and special objectives. General objectives are directed towards entire program, whereas special objectives are focused on each components. As mentioned by Sudjana (2002:48), special objectives of program evaluation consist of 6 (six) points, viz. to:

1. Give recommendations to program planning.

2. Suggest a recommendation to decision makers who related to next step, expanding or stopping the program;

3. Suggest a recommendation to decision makers about modification or improvement of the program; 
4. Give recommendations which related to support factors and obstacles of the program;

5. Give recommendations for motivation and development activity (control, supervision and monitoring) to program providers, managers, and executors, and;

6. Present data about theoretical basic for evaluation of non-formal education program.

\subsubsection{Description of Curriculum year 2013}

Curriculum is a set of plans and regulations about objectives, contents, study materials, and methods, used as guide to organize learning activity to achieve particular educational objectives. (UU nomor 20 tahun2003;PPnomor 19tahun2005).

According to Kemendikbud, (in an article of Husanah and Setyaningrum, (2013: 5) this curriculum 2013 is not a new curriculum in the world, because similar curriculums have been applied in Finland, Germany, and France. Of course, without turning a blind eye to any drawbacks, we need to take anticipation for this new curriculum. It is better to be responded as a challenge to enhance education quality in this country.

Conceptually, curriculum is an education respond toward society and nation needs to build the younger generation. Pedagogically, curriculum is an education arrangement that gives a chance for students to develop their potencies in a happy and appropriate learning situation for them to achieve quality which are wanted by the society and country. Juridical, curriculum is a public policy that based on basic philosophy of the country and juridical decision in education sector.

\subsubsection{Objectives of Curriculum 2013}

Objectives and functions of curriculum 2013 specifically refers to Mengenai tujuan dan fungsi kurikulum 2013 secara spesifik mengacu pada Act No. 20 of 2003 about national education system (Sisdiknas). In the law of this Sisdiknas it was said that function of curriculum is to develop abilities, shape dignified characters and cultures to enrich the life of our nation. Whereas the objective is to develop potencies of students thus become man of faith and cautious to God, noble, healthy, knowledgeable, skill full, creative, independent, and responsible; next these are the objectives of curriculum 2013 that mentioned by Fadlillah 2014 (24-25) :

1. To increase the quality of education with balancing hard skill and soft skill through good behavior, creativity, and knowledge to face various global challenges that keep growing.

2. To shape and increase human resources that are productive, creative, and innovative as basic to develop this nation.

3. To alleviate the burden of teachers in delivering learning materials and preparing teaching administration, because government already prepare all curriculum components along with textbooks used in learning activity.

4. To increase role of central and regional government and community members in a balanced way to determine and control quality of curriculum implementation in each level of education.

5. To increase healthy competition between education units in terms of education quality to be achieved. Because freedom was given to the school to develop curriculum 2013 according to condition of education unit, student needs, and regional potency.

\subsubsection{Principles of Curriculum 2013 Development}

Curriculum 2013 for primary and middle school level was developed of school and school committee based on the graduate's competency standards and content standards and curriculum preparation guide that was made by BSNP. Curriculum was developed based on these principles:

1. Focuses on potential, development, needs, and interests of students and their environments.

2. Diverse and integrated, curriculum was developed with regards to character diversity of students, regional condition, and level and type of education, without discriminate religion, race, culture, tradition, socioeconomic status and gender.

3. To understand of knowledge, technology and art, curriculum is developed on the basis that knowledge, technology and art develop dynamically, therefore the spirit and the content of curriculum encourage students to follow and properly utilize these developed knowledge, technology and art.

4. Relevant to needs; curriculum development was done by involving stakeholders to secure relevance of education with the needs, which including needs of social life, business life and work life.

5. Thorough and continuous; curriculum covers overall dimensions of competency, study fields 
and subjects that are planned, and presented continuously between all education levels.

6. Lifelong learning; curriculum is directed to the process of developing students culture which lasts for lifetime.

7. Balance between national and regional interests; curriculum is developed on the basis of national and regional interests to build life of society, nation and state.

\subsubsection{Planning of Curriculum 2013}

Planning, as said in the first language, is an early function of management. Management itself, according to Hersey and Blanchard (in Sudjana 2004:58), was given limit:" As working with and through individuals and groups to accomplish organizational goals".

Planning is a systematic process to reach a decision about action to be taken in the future. It was said to be systematic because planning was done using particular principles. If the planning is done well then most likely that the implementation process will be good. Planning contains an understanding of what has been done, problems encountered and solutions, and implementation of proportionally determined priority activities. The planning of educational programs serves as an attempt to portray preparation of a series of actions that have been taken and to direct or employ limited resources efficiently and effectively, to achieve organization objectives.

\subsubsection{Implementation of Curriculum 2013}

According to Permendikbud 81A tahun 2013 (in Fadlilah 2014:179-185) it was described that learning activity is an educational process that gives chance to students to develop their potential into ability that growing into behaviour, knowledge and skills, which needed to live and adaptate in the life of society, nation, and state, and contribute to welfare of humankind. Therefore, learning activity is directed to foster potentials of students into expected competencies.

Curriculum 2013 is a new curriculum that more emphasize achievement of behaviour, knowledge and skill competencies, which included in hard skill and soft skill competencies. According to those three competencies, learning activity needs to be arranged in such a way to achieve the main objective of education. Regarding to this matter, there are a few principles which need to be noticed by teachers in learning activity, i.e.: (1) student centered, (2) develop student creativity, (3) create fun and challenging conditions, (4) have values, ethics, aesthetics, logics and kinaesthetic, (5) provide diverse learning experience through application of various strategies and methods of education which fun, contextual, effective, efficient and meaningful.

Implementation of curriculum 2013 divided into three activity, i.e. early, core, and final. These three activities composed into one in a learning activity and inseparable.

1. Early activity is an preliminary action before entering the core of learning. Generally, time needed for early action is 15 minutes. In this action, things that could be done by teachers are: (1) preparing students psychologically and physically to follow the learning activities, (2) starting with prayer and greetings, (3) asking questions about the material that has been studied and related to material that will be studied, (4) leading students to a problem or a task which will be performed to learn a material and explain the learning activity objectives or $\mathrm{KD}$ to be achieved, (5) conveying outline of material scope and description about acitivities that will be done by students to solve problem or task, (6) contextually giving study motivations to students in accordance to benefits and application of learning materials in daily life, using examples and local, national, and international comparisons.

2. Core activity is the most important and key action in learning process. Because, in this action, the learning materials will be delivered and given to students. Core activity is a learning process to achieve the purpose, done interactively, inspiring, fun, challenging and motivate students to be an active information seekers, and giving enough space for initiative, creativity, and independence, in accordance to talents, interests and physical psychological development of students.

3. Final activity or closer is an activity which meant for ending the learning process. This action was used by teacher to draw conclusions from the newly learned material. Time needed for this activity is about 10 minutes. A few activities that could be done by teachers and students at the end of learning activity are: (1) drawing conclusions from overall learning activities and the obtained results, then together determine the direct or indirect benefits of the results, (2) giving feedbacks to process and results of learning activities, (3) doing followup in the form tasks, individual or group, (4) 
giving information about learning activity for the next meeting.

Success of those learning activities above depend on active interaction between teachers and students, and between students.

\subsubsection{Monitoring and Evaluation of Curriculum 2013}

Success of a program could be seen from the plan, process, and results, to see if the result compatible with the plan. To achieve a good implementation of plan that had been planned, management needs to prepare a program, which is monitoring. Monitoring intended to find facts, data, and information about program implementation, if the process of implementation was done according to the plan. Findings from monitoring program are information for evaluation process, then the result will decide if the planned program and implemented program reached an appropriate result or not.

Monitoring and evaluation are parts of management system, viz. planning, organization, implementation, and evaluation. Without evaluation we could not find out the condition of evaluation objects in the plan, implementation, and result. Evaluation (Evaluasi, bahasa Indonesia) term has become a vocabulary in Bahasa Indonesia, but this term originated from an English word, evaluation, which means assessment or appraisal (Echols dan Shadily,2000:220). Whereas according to sense of the term "evaluation is a well-planned activity to understand the condition of an object using instruments and the results will be compared to benchmark to find the conclusion "(Yunanda:2009).

Deputy Minister of Education and Culture, Musliar Kasim, said that monitoring and evaluation results of curriculum 2013 will be used as basis mentoring to target teacher. This monev aims to know how far the understanding of teachers and students about Curriculum 2013. Several schools have been using this curriculum since July 15 , and some schools have been using it since last August 19. According to the Deputy, Kemendikbud feels confident that this curriculum application could be monitored through direct monitoring in the field. Result of monitoring and evaluation could be used as objects for planning the implementation for school year 2014/2015.

Minister of Education and Culture Muhamad Nuh also confirmed that Kemendikbud has performed monitoring and evaluation of curriculum 2013 through Sensus Kurikulum 2013 to discover benefits and disadvantages, of each school that implementing curriculum 2013. Monitoring and evaluation are done to repair and to repair mentoring strategy for each teachers. Mendikbud said that will repair curriculum 2013 if disadvantages were found. Curriculum 2013 is very important to maintain moral and face the challenges of the times, because in the new curriculum, explicitly, there are character and manner education.

It could be concluded that monitoring and evaluation are the benchmark to assess success of a program that has been done, whether the program is a success or a failure.

\subsection{School Principal Competence Theories}

\subsubsection{School Principal Management Competence}

Regulation of the Minister of National Education (Permendiknas) Number 13 year 2007 about standards of school/madrasah principals or headmasters has established that there are five dimensional competencies of the school/madrasah principals or headmasters, i.e: personality, management ability, entrepreneurship, and supervision dan social ability. In order to build competency of school/madrasah principal to master these five dimensions, Direktorat Tenaga Kependidikan has attempted to compose Bahan Belajar Mandiri (BBM). This BBM is composed with purpose that the principals of school or madrasah can learn by themselves independently without help or have to wait for a task as a training (diklat) participant, or depending on facilitators, providers, times and places.

With this composed BBM it was hoped that principals of school or madrasah can learn independently anywhere anytime. Principals of school or madrasah are teachers who was given extra tasks as a principal, therefore he/she needs to have competencies that were required, i.e. have pedagogic skill, personality, social, and professional. According to this reality then the attempt to enhance competency of principals of school or madrasah was done through various strategies. One strategy to reach all principals of school or madrasah instantly is to use Forum Kelompok Kerja Kepala Sekolah/ Madrasah $(K K K S / M)$ as an instrument to learn together.

Principals of school or madrasah in that forum can share knowledge and experience, together they enhance their competency and performance in an intimate peer's environment. This BBM intended to give an understanding and motivation to principals of 
school or madrasah to finish problems in their schools through mastering management competency.

With this management competency, then the performance of principals in leading the school could be assessed, by competency in pedagogic and management. These include planning, implementation and evaluation.

\section{DISCUSSION}

Particular research of academic lecturers found that (a) Facilities and infrastructures are direct responsibilities of District Government and Education Authority for school, and Regional and District Office of Ministry of Religious Affairs for madrasah. Availability of classrooms and teachers that qualified for standards and competencies, is still below the minimum service standards in Madrasah. contoh penyediaan ruang kelas dan penyediaan guru yang memenuhi Gorontalo District, (b) furthermore, it was found that educational support facility in the form of laboratory, which equipped with instruments for IPA, IPS and ICT subjects, is still not available in all school, only about $58 \%$ have it, either in SD, MI, SMP, or STs which located in Gorontalo District.

Finding from student research about school culture is that developing school culture basis on the ESQ through various intracurricular activities in SMP Negeri I Gorontalo, in this case was learning process inside the classroom, teachers were applied greeting culture, adaptating student to pray before study for good learning activity, growing a sense to care for eachother through providing positive motivations. To develop school culture based on ESQ in learning program outside the class, not all teachers conduct learning activity outside the class only few particular subjects like physical education and IPA (natural science), the rest of teachers just emphasize the attitude formation, moreover school culture development based on ESQ could be done through various extracurricular activities, like: sports, art, scout activities and religious activities.

Readiness of human resources in the development of curriculum 2013 in SDN 33 Kota Selatan based on study result data could be seen from: 1) willingness dimension (dimensi kemauan), 2) ability dimension (dimensi kemampuan), and 3) motivation dimension (dimensi motivasi).

Enthusiasm of teachers to attend the training of curriculum 2013 program with guidance of school principal. Furthermore, curriculum 2013 require each teacher to able using computer; through KKG (Kelompok Kerja Guru) activities, teachers who are not yet able to use computer can directly learn from principal and other teachers whom able to use computers.

Teachers have not been able to understand well the curriculum 2013. Examples, the teachers are still hassles with the thematic education curriculum 2013, they also feel confused when filling student report cards, and there are still some teachers who are not yet able to use computer, become drawbacks in implementation of curriculum 2013. Only half of teachers have desire to learn, generally the younger ones. Older teachers tend to be indifferent and just expect some help from capable teachers.

Responsibility as teacher is a main factor of motivation for teacher in implementing curriculum 2013. Duty of a teacher is to teach. Meanwhile, other factors that could give motivation to teacher are school environment, school social environment, and the needs of the teachers themselves.

From student research findings of implementation evaluation of curriculum 2013 (K13) it was found that school as practitioner of K-13 did it carelessly. It is proved by the condition of SDN 33 Kota Selatan Gorontalo which is clearly not ready to implement K-13 in any case, but the school still elected to become a model school for impelementation of curriculum 2013. From research results, generally SDN 33 Kota Selatan Kota Gorontalo is not ready to implement curriculum 2013. Not only because of teachers are not competent enough to implement curriculum 2013, but also because the curriculum itself is burdensome for the teachers. Furthermore, the supporting facilities and infrastructures are important factors of the success of curriculum 2013. Unpreparedness of school facilities and infrastructures like textbooks, laboratories, computers, etc., become serious obstacles for school to implement curriculum 2013. Still, it was found that ICT readicess becomes an optimal term for implementation of K-13. Education technology in curriculum 2013 aims to make learning process become more varied, not only one way, make student more creative, and certainly not boring. eduntuk membuat pelajaran lebih variatif, tidak satu arah, membuat siswa lebih kreatif dan pastinya tidak membosankan. Readiness of education technology in SDN 33 Kota Selatan is very minimal, suggest that this school is not ready for curriculum 2013.

\section{CONCLUSIONS}

Competency of school principal in managing a primary school institution is very important, especially in developing a conducive school culture 
including managing facilities and infrastructures to support implementation of curriculum in school. Competency of school principal is intentionally formed through various training in hope that the school he/she lead can developed well, in terms of quality and quantity. The development this school is also related to how principal develops a conducive school culture to achieve a good learning process.

To organize education, we need (1) clear objectives, (2) quality planning and estimation of outcomes, (3) education process, (4) input (5) resources, and (6) facility and infrastructure. The development of school culture on the basis of ESQ through intracurricular activities, in this case the learning process in class, teachers applied the cultural greetings, accustomed to pray before class started so the learning process will run well, fostered a sense of caring to each other by giving positive motivations. Readiness of human resources (SDM) in developing curriculum could be seen from: 1) willingness (dimensi kemauan), 2) ability (dimensi kemampuan) and 3) motivation (dimensi motivasi).

\section{REFERENCES}

[1] Arikunto, Suharsimi. 2002. Prosedur Penelitian Suatu Pendekatan Praktek. Jakarta:PT Rineka Cipta

[2] Arikunto, Suharsimi. 1993. Organisasi dan Administrasi Pendidikan Teknologi dan Kejuruan.Jakarta: PT GrafindoPersada

[3] Ad-Duweisy, Muhammad Abdullah. 2005.Menjadi Guru yang Sukses dan Berpengaruh, Terjemahan, judul asli : alMadrasah wa al-Maharat al-Taujih. Surabaya : eLBA

[4] Altbach, Philip G. 1991. "Introduction". Textbook in American Society. New York: SUNY Press

[5] Asmani, Jamal Ma'mur. 2009.Tips Menjadi Guru Inspiratif, Kreatif dan Inovatif. Jogjakarta : DIVA Press

[6] Asyhar, Rayandra. 2011. Kreatif Mengembangkan Media Pembelajaran. Jakarta : Gaung Persada (GP) Press

[7] Bafadal, I. 2003.Manajemen Perlengkapan Sekolah Teori dan Aplikasi. Jakarta: PT Bumi Aksara

[8] Bungin, Burhan. 2000. Analisis Data Penelitian Kualitatif : Pemahaman Filosofis dan Metodologis ke Arah Penguasaan Model Aplikasi. Jakarta : Rajawali Pers
[9] Crowther, J. 1995. Oxford Advanced Learner's Dictionary Of Current English. AS: Oxford University Press

[10] Daryanto, M. 2006. Administrasi Pendidikan. Jakarta: PT. Rineka Cipta

[11]Depdikbud. 1994. Kamus Besar Bahasa Indonesia. Jakarta : Balai Pustaka

[12] Dharma, A. 2000. Manajemen Pengembangan Kurikulum. Bandung : Remaja Rosdakarya

[13] Dimyati. 2002. Belajar dan Pembelajaran. Jakarta : Rineka Cipta

[14]Hamalik, Oemar. 2011. Dasar-Dasar Pengembangan Kurikulum. Bandung : Remaja Rosdakarya

[15] Hamdani, Ihsan. 2001. Filsafat Ilmu Pendidikan. Bandung : Cv Pustaka Setia

[16]Hamzah. 2011. Profesi Kependidikan: Problema, Solusi, dan Reformasi Pendidikan di Indonesia. Jakarta : Bumi Aksara.

[17]Moleong, Lexy J. 2011. Metode Penelitian Kualitatif. Bandung : Remaja Rosdakarya

[18] Mulyasa, E. 2006. MenjadiGuru Profesional. Bandung : PT Remaja Rosda Karya

[19]Mulyasa, E. 2004. Manajemen Berbasis Sekolah.Bandung: PT Remaja Rosdakarya

[20] Muslich, M. 2010. Text Book Writting: Dasardasar Pemahaman, Penulisan, dan Pemakaian Buku teks. Jogjakarta : Ar-Ruzz Media

[21] Nasution, S. 2008. Kurikulum dan Pengajaran. Jakarta : Bumi Aksara

[22]Permana. 2008. Standar Kompetensi dan Sertifikasi Guru. Bandung : Remaja Rosdakarya

[23] Prastowo, A. 2012. Panduan Kreatif Membuat Bahan Ajar. Yogyakarta : Diva Pres

[24] Republik Indonesia. 2003. Undang-Undang Sistem Pendidikan Nasional. Jakarta : Sekretariat Negara

[25] Republik Indonesia. 2005. Permendiknas tentang Standar Nasional Pendidikan. Jakarta : Sekretariat Negara

[26] Republik Indonesia. 2013. Permendikbud tentang Standar Proses Penilaian. Jakarta : Sekretariat Negara

[27] Sanjaya, Wina. 2010. Kurikulum dan Pembelajaran : Teori dan Praktik Pengembangan Kurikulum Tingkat Satuan Pendidikan (KTSP). Jakarta : Kencana Predana Media Group

[28] Slameto. 1998. Belajar dan Faktor - Faktor yang Mempengaruhinya. Jakarta : Rineka Cipta

[29] Slavin, R.E. 2011.Educational Psychology: Theory and Practice terjemahan Psikologi Pendidikan: Teori dan Praktik. Jakarta : PT Indeks 
[30] Soemanto, Wasty. 1998. Psikologi Pendidikan. Jakarta : Rineka Cipta

[31] Subagyo, Joko P. 1997. Metode Penelitian Dalam Teori dan Praktek. Jakarta : Rineka Cipta

[32] Sudjana \& Ibrahim. 2007. Penelitian dan Penilaian Pendidikan. Bandung : Sinar Baru Algensindo

[33] Sugiyono. 2008. Metode Penelitian Pendidikan : Pendekatan Kuantitatif, Kualitatif, dan $R \& D$. Bandung : Alfabeta

[34] Sugiyono. 2009. Metode Penelitian Pendidikan : Pendekatan Kuantitatif, Kualitatif, dan $R \& D$. Bandung : Alfabeta
[35] Sumadi, Suryabrata. 1998. Psikologi Pendidikan. Jakarta: Raja Grafindo Persada

[36] Suparlan. 2008. Menjadi Guru Efektif. Yogyakarta : Hikayat Publishing

[37] Syaodih, Nana. 2005. Pengembangan Kurikulum Teori dan Praktek. Bandung : PT Remaja Rosdakarya

[38] Tarigan, Henry Guntur \& DjagoTarigan. 1986. Telaah Buku Teks Bahasa Indonesia. Bandung : Angkasa

[39] Trianto, dkk. 2006. Hak Serta Kewajiban Pendidik Menurut Undang-undang Guru dan Dosen. Jakarta : Prestasi Pustaka

[40]Yusnawati. 2007. Kesiapan Berwirausaha Siswa Jurusan Kecantikan. 